\title{
Determinant of Indonesian Banking Profitability: Case Study Dual Banking System
}

\author{
M. Nur Faaiz F. Achsani \\ International Islamic University of Malaysia, Malaysia \\ Corresponding email: mnurfaaiz@gmail.com \\ Salina H. Kassim \\ International Islamic University of Malaysia, Malaysia, ksalina@iium.edu.my
}

Article History

Received: November 29 $9^{\text {th }}, 2020$ | Revised: January 23 ${ }^{\text {rd }}, 2021$ | Accepted: March $6^{\text {th }}, 2021$

\section{Abstract}

Islamic banking is considered as the perfect alternative of the current conventional financial system. However, there is still a huge amount of criticisms in terms of its practice, with many claims that Islamic banking and finance simply replaces conventional banking terminology and offers near-identical services to its clients but at a higher cost. The objective of this study is to make a comparative empirical assessment on the determinants of profitability between the Islamic and conventional banks in Indonesia. The panel data regression is applied to analyze the relationship between profitability indicators and both industry and country level characteristics. As far as the author knows, only few studies compare the profitability of Indonesian Islamic banks and conventional banks, especially in using econometrics approach. From the empirical result in the combined model, it is known that conventional banks are more profitable than Islamic banks. Compared to the combined regression, there is no significant difference in terms of significance of the independent variables and its relationship with the dependent variable for the conventional bank regression. Conventional banks are more familiar for the community due to the long operation compared to Islamic banks. Socialization needs to be done with some approach starting from mosques and Islamic schools. The development of supporting industries such as halal industry and halal tourism are also important to increase the demand for Islamic banking product. Beside increasing the demand, efforts to increase the economics of scale is also important with various efforts such as merger or acquisition.

JEL Classification: G18, G21, G28

Keywords: Conventional Banks, Islamic Banks, Panel Data, Profitability Determinants

Type of paper: Research Paper

@ IJIEF 2021 published by Universitas Muhammadiyah Yogyakarta, Indonesia All rights reserved

DOI:

Web:

https://doi.org/10.18196/ijief.v4i0.10464

https://journal.umy.ac.id/index.php/ijief/article/view/10464

Citation:

Achsani, M. N. F. F., \& Kassim, S. (2021). Determinant of Indonesian banking profitability: Case study dual banking system. International Journal of Islamic Economics and Finance (IJIEF), 4(SI), xx-xx. DOI: https://doi.org/10.18196/ijief.v4i0.10464. 


\section{Introduction}

\subsection{Background}

The conventional system banking system caused some problems to the economy in general. It is evidenced by the number of financial crisis that happened in the past. The implication of a financial crisis can be felt worldwide. In the case of financial crisis 2007, even Lehman Brothers Holding filed for bankruptcy which is not predicted by everyone since the huge asset they have. The system also creates inequality problem. Majority of the growth of global wealth are also going to the rich people while poor got nothing (Oxfam, 2018). While in the other side of the world, more than 820 million people are still hungry today. This stat remains virtually unchanged in the past three years (FAO, IFAD, UNICEF, WFP, \& WHO, 2019). Interest or usury is an overhead charge which does not form part of any factor of production. Usury is a tool used by the rich to earn more wealth. (Swartz, Itumeleng, Wankie, Jeelabdeen, \& Kumar, 2013).

The dominance of the conventional bank which are operating on the usurybased transactions has ruined the economy worldwide. Initiatives has been taken by Muslim scholars to empower the Shariah rulings in order to overcome the problem. It can be seen from the establishment of the international standard-setting bodies, such as the Islamic Financial Services Board (IFSB), Accounting and Auditing Organization for Islamic Financial Institutions (AAOIFI) and other organizations. This same spirit also spreads to Indonesia in the early 1990s. This great momentum is reflected by the Act of the Republic of Indonesia Number 7 of 1992 as the legal statutory as the beginning of a new chapter from single banking system into dual banking system. The first Islamic bank in Indonesia starts to operate even before the dual banking act take effect. The signature of the establishment Bank Muamalat Indonesia was held in 1991 as a formal recognition from the government relating the presence of the bank. The presence of Islamic banking is expected to be accepted by the market easily. According to Badan Pusat Statistik (2010), the amount of Muslim in Indonesia reached more than 207 million people or about $88 \%$ of the total population. The growth in Islamic banking is heavily influenced by the number Muslim population (Imam \& Kpodar, 2010). 


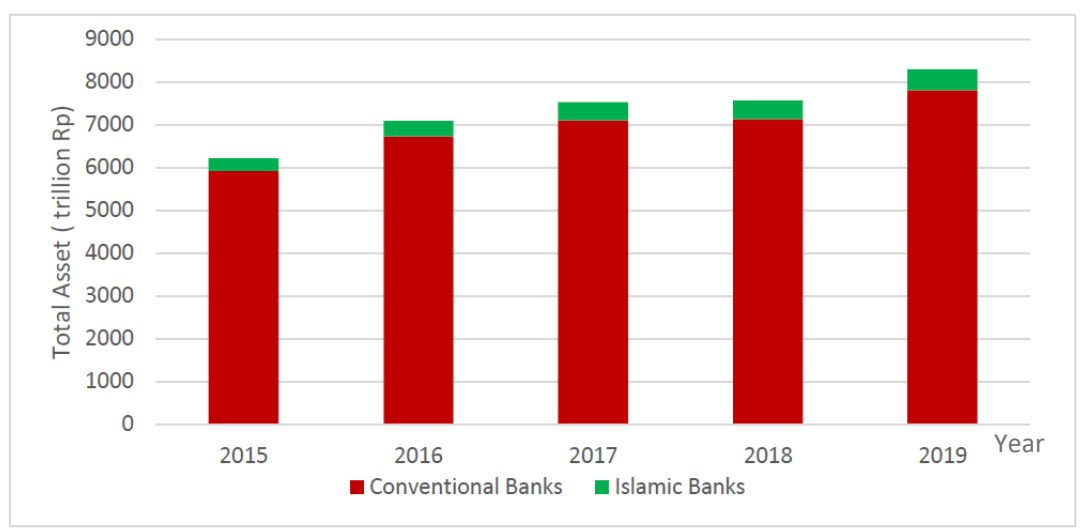

Figure 1. Total Asset of Indonesian Bank 2017 - 2019

Source: (Otoritas Jasa Keuangan, 2013-2019)

However, the size of Islamic bank in Indonesia reveals the other way. The combination of all Islamic banking asset is still lower than the biggest conventional bank in Indonesia which can be seen in the Figure 1. The asset position should influence the profit of the related bank. Larger banks tend to be more successful (Hassan, 2018). Is conventional bank more profitable than Islamic bank in Indonesia? It is interesting to see the reason behind the stagnant capitalization of Indonesian Islamic banks by analyzing the determinants of profitability or some called it as a " $5 \%$ trap". Numerous studies tried to analyze topic with different conclusions as the result. As far as the author knows, only few studies compare the profitability of Islamic banks and conventional banks, especially in Indonesia. This study will fill the research gap. It will enrich the literature by considering the uniqueness of Islamic banks and compared it with conventional banks in terms of profitability determinants.

\subsection{Objective}

This study aims to analyze the impact of internal and macroeconomic variables on the performance of Islamic and conventional bank in Indonesia during the period from 2011 until 2018. The profitability of banks is examined by implementing bank size, debt ratio, and equity/asset as bank specific while GDP and inflation as macroeconomic conditions. Return on asset represents the bank profitability as the dependent variables. The objectives of the study are as follows:

1. To identify the more profitable type of bank in Indonesia

2. To analyze and compare the factors that determine the profitability level of conventional and Islamic banks in Indonesia during period 2011-2018

This study will benefit the management of the banks to maximize their profit. The related parties such as the depositors and borrowers of the bank could 
gain benefits to understand the inside of the company where their money being utilized. For the government, in order to increase the market share of financial products which is compliant with the shariah principles, the comparison of the variables which drive the profitability of both banking will be important. By referring to this study, the authorities can arrange the proper policy to maximize the profitability of Islamic banks. This study is also in line with the objective of National Islamic Finance Committee, to promote the Islamic economics. The central bank of Indonesia could also benefit from this study due to the involvement of some macroeconomics factor such as GDP and inflation in the regression. The stability of the financial system as one of the objectives of Bank Indonesia can also be linked with this study because both types of banking, conventional banking and Islamic banking is compared. The rest of the paper is organized as follows: section 2 shortly reviews the literature regarding the determinants of banks profitability, while section 3 presents the methodological approach adopted and section 4 the results obtained. Finally, the conclusions are drawn in section 5.

\section{Literature Review}

\subsection{Previous Studies}

There are empirical studies that have been studying the determinants of profitability in conventional banks. Alexiou and Vogiazas (2009) study the profitability determinants of conventional banks in Greece. The empirical findings show that majority of the bank-specific determinants were significantly affecting bank performance. The result become even more ambiguous when the macroeconomic factors were considered.

In the case of Turkey, Alper and Anbar (2011) study the determinants performance of conventional banks. The empirical findings show that asset size and non-interest income have a significantly positive effect on bank profitability. However, size of credit portfolio and loans under follow-up have a significantly negative impact on bank performance. When it comes to macroeconomic variables, real interest rate is the only variable that affects the performance of the banks.

In another study, Nouaili, Abaoub, and Ochi (2015) study the profitability determinants of conventional banks in Tunisia. The empirical findings show that quotation, capitalization and privatization effect the performance of the bank positively. Meanwhile, bank size, concentration index and efficiency are affecting the performance of the bank negatively. When it comes to the macroeconomic variables, GDP affect the performance positively and inflation affect it negatively. 
There are also empirical studies that have been studying the determinants of profitability in Islamic banks. In the case of Bahrain Islamic banking performance, Hidayat and Abduh (2012) study the profitability determinants of Islamic banks in Bahrain. The result shows that LTA, LEQ, and LOHE are significantly influence Islamic bank's performance in Bahrain. In addition to that, in the case of Bahrain Islamic bank in selected countries, assets size, capital adequacy, loans to assets and assets management affect the bank performance positively (Masood \& Ashraf, 2012).

In addition to that, Hasan and Ahmed (2019) study the profitability determinants of Islamic banks in Bangladesh. The result finds that majority of the variables are significantly affect the bank performance. CRAR and cost-toincome affect the bank performance negatively while liquidity and bank size affect positively. Moreover, NPI is found affecting ROA positively. In the case of bank in Indonesia and Hongkong, Khediri and Ben-Khediri (2009) suggests that management efficiency and capitalization enhance the performance of the bank. Inflation, economic growth and bank concentration is found affecting it positively.

Alongside studies focusing in the determinant variables of Islamic and conventional banks separately, there are also some studies focusing on the determinants of profitability in Islamic banks and conventional banks comparatively Abduh, Omar, and Mesic (2013) study the profitability determinants of Islamic and conventional banks in Malaysia. The results show that only liquidity ratios and macroeconomic condition affect the profit of the bank. The final result under FEM shows that types of bank and macroeconomic condition significantly affects bank profitability. This study did not separate Islamic and conventional banks in a different model. Therefore, the difference of profitability determinants cannot be identified.

Abduh and Issa (2018) study the profitability determinants of Islamic and conventional banks in Kuwait. The result suggests that credit risk, liquidity and efficiency significantly affecting the profitability on both types. To illustrate the Kuwait conventional banking sector, credit risk and operating expenses significantly affect the profitability in a negative relationship. On the contrary, efficient management significantly affects profitability in a positive relationship. When it comes to macroeconomic conditions, inflation has shown a significant and negative impact towards profitability. Above all, the crisis represented by a dummy variable has a negative impact upon profitability. Similarly, credit risk and liquidity risk has also shown a significant and negative impact upon profitability of Kuwait Islamic banking sector. Moreover, size and capitalization affect the profitability positively. However, indicator of operating efficiency has shown a significant and negative relationship with the profitability. Talking of macroeconomics conditions, GDP 
effect the performance of bank positively. In conclusion, the profitability of Islamic bank and conventional bank are driven by a different force.

Ali (2018) study the profitability determinants of Islamic and conventional banks in Pakistan. The study suggests that liquidity affects the profitability of Islamic and conventional bank in the same way. Both type of banks did not have a significant relationship with liquidity. In terms of credit risk, either the profitability of Islamic or conventional banks are affected significant and negatively. In terms of efficiency and bank size, both Islamic and conventional bank are significantly affected the profitability positively. However, when it comes to macroeconomic conditions, both type of banks show a different pattern. For the case of inflation, Islamic banks are affected positively while conventional banks are affected negatively. GDP did not affect Islamic bank's profitability but it got a negatively significant relationship with the conventional banks. This study suggests that Islamic bank are driven by the same force in the case of internal variable but it is driven by a different force related to the external variables.

There is a literature gap in evaluating the profitability of both type of bank in Indonesia to be filled by this study. It is proofed by the non-existence of this topic by found by the author. The existing literatures suggest that there are various result relating to the determinant of profitability. The selection of the dependent and the independent variable is also various, enrich the explanation of this topic even further. In terms of comparison of Islamic bank and conventional bank, majority of the previous literature suggest that Islamic bank and conventional are generally driven by the different force. As far as the author knows, only two studies that suggest that Islamic bank and conventional bank are driven by the same force.

\subsection{Conceptual Framework}

In order to measure performance, there are three main methods used mainly; profitability, efficiency, and productivity. This research paper used profitability approach to measures operating bank performance in Indonesia therefore, the research paper used several ratios in order to measure profitability. 


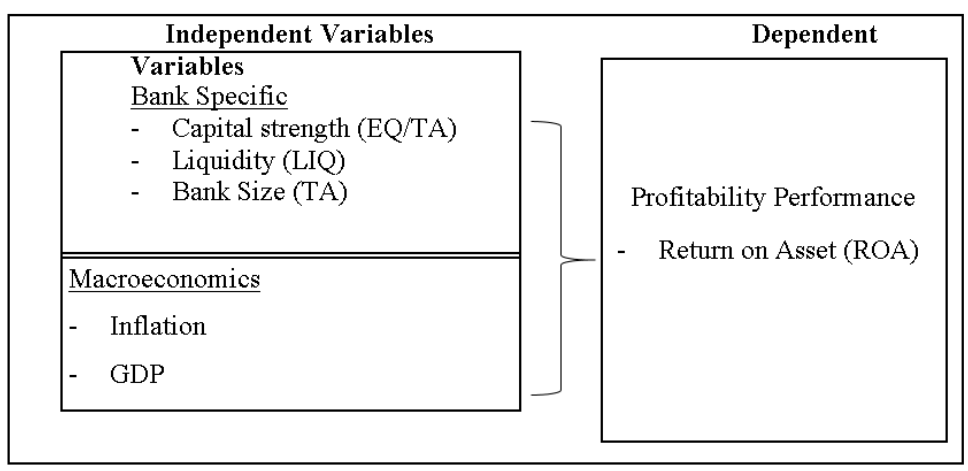

Figure 2. Conceptual Framework of Research Model

Source: (Abdu, 2015)

As we can see in the Figure 2, ROA is used as the dependent variable in this study. It shows the percentage of profit to total assets. ROA was treated as measure of financial performance in the research. Numerous papers used ROA as to assess the profitability performance such as Alexiou and Vogiazas (2009). The first internal variable is natural log of total asset. Size is used as a proxy in order to capture the cost advantage associated with size. Usually, the impact of bank size on profitability is expected to be positive. Numerous papers used size ratio as to assess the profitability performance such as Alper and Anbar (2011). The next internal variable is liquidity ratio. It is calculated by total loans/total asset, a percentage of the bank's asset attached to loans. Higher percentage indicates lower liquidity. Numerous papers used liquidity ratio as to assess the profitability performance such as Abduh, Omar, and Mesic (2013).

The ratio of capital strength, calculated by total equity/total asset, is a percentage of a bank's risk weighted credit exposure. It also referred to sufficient amount of equity absorbed by any shocks that the bank might experience. Numerous papers used capital strength as to assess the profitability performance such as (Ali, 2018). In this research, capital strength is expected to have a positive impact on the bank's profitability. When it comes to macroeconomic variables, GDP and inflation is used in this study. Numerous papers used GDP as to assess the profitability performance such as Masood and Ashraf (2012) and Tariq, Usman, Mir, Aman. In terms of type of bank, the dummy variable suggests a statistically significant result at $1 \%$ with a negative relationship. In other word, Islamic banks (dummy $=1$ ) are less profitable compared to conventional banks $(d u m m y=0)$ in the period studied. 


\section{Methodology}

\subsection{Data}

The data consists of nine Islamic banks and sixty conventional banks from 2011 until 2018 (see Appendix A). The study excludes the rural banks despite the presence of Islamic rural banks. In order to be included, there are two conditions; the bank must be operating in Indonesia and should have complete data which will be used as the variables within the period of study from 2011 to 2018. The data for bank specific variable is mainly taken from the annual report in each bank and the data for the macroeconomic variables are taken from World Bank.

\subsection{Method}

In econometrics, there are three types of data; cross section, time series, and panel data. Panel data is a combination of time series data and cross section data. It can be said that panel data is the same parameters observed in the cross-section data but in certain period. This literature is using static panel data as the method to achieve the research objective. According to (Gujarati, 2003), the difference of panel data regression can be seen in the double subscript in every variable. The equation of static panel data is written below:

$$
Y_{i t}=\beta_{1 i}+\beta_{2} X_{2 i t}+\beta_{3} X_{3 i t}+u_{i t}
$$

\subsection{Model Development}

The main approaches to the fitting of model usually are the fixed effect model and the random effect model. This is because there is a problem in the assumption of pooled panel data regression. The intercept and slope of the regression are assumed constant among individuals and time that is not suitable with the purpose of the panel data regression usage. Fixed effect model is used when the individual effect and the time effect is correlated or when the pattern is not random. According to this assumption, error component from individual effect and time effect can be a part of the intercept. In order to do the one-way error form. Random effect model is used when the individual effect and the time effect is not correlated or when the pattern is random. With this condition, error component of the individual effect and the time effect is included as an error. 
Table 1. Data and Variables

\begin{tabular}{lll}
\hline \multicolumn{1}{c}{ Variables } & \multicolumn{1}{c}{ Description } & \multicolumn{1}{c}{ Source } \\
\hline \multicolumn{1}{c}{ Dependent variables } & & \\
ROA & Return on Asset & Annual Report/OJK \\
Independent (Internal) & & \\
SIZE & Total Asset & Annual Report/OJK \\
LIQ & Total Loans/Total Asset & Annual Report/OJK \\
EQTA & Total Equity/Total Asset & Annual Report/OJK \\
DUMMY & Equal 1 if Bank is Islamic or 0 Otherwise & Annual Report/OJK \\
Independent (External) & & \\
INF & Inflation Rate & World Bank \\
GDP & Gross Domestic Product & World Bank \\
\hline
\end{tabular}

To reflect the variables described in the table 1 , the regression is formulated as follows:

$$
R O A_{j, t}=\beta_{0}+\beta_{1} \text { Size }_{j, t}+\beta_{2} L I Q_{j, t}+\beta_{3} \mathrm{EQTA}_{j, t}+\beta_{4} \mathrm{GDP}_{j, t}+\beta_{5} I N F_{j, t}+
$$

$\beta_{6}$ Dummy $+\varepsilon_{j, t}$

$$
R O A_{j, t}=\beta_{0}+\beta_{1} \text { Size }_{j, t}+\beta_{2} L I Q_{j, t}+\beta_{3} \mathrm{EQTA}_{j, t}+\beta_{4} \mathrm{GDP}_{j, t}+\beta_{5} I N F_{j, t}+
$$

$\varepsilon_{j, t}$

In the first equation known as the combined regression, relationship between the dependent variables, $\mathrm{ROA}_{\mathrm{j}, \mathrm{t}}$ (return on asset $\mathrm{j}$ the bank in period $\mathrm{t}$ derived) with the independent variables are tested in a combined model. Size is the natural log of total asset. $\mathrm{LIQ}_{\mathrm{j}, \mathrm{t}}$ is total loan divided by total asset which measure the liquidity $j$ the bank in period $i$ derived. EQTA $_{j, t}$ is equity divided by total asset which used as proxy for capital strength $j$ the bank in period $t$ derived. Dummy is used to distinguish the Islamic bank and conventional banks, where the dummy $=1$ refers to Islamic banks and dummy $=0$ refers to conventional banks. Furthermore, in order to isolate the effect of bank's characteristic on profitability, growth of real GDP and inflation is included in the model as an external determinant. This model is generated to find out whether the type of the bank affects the probability of the bank, represented by the significance of the dummy variable.

In the separated model, we are separating the data based on the type of the bank. There will be a model for Islamic banks and one for conventional banks.

These models are produced to see the effects of these determinants on profitability for both Islamic banking as well as conventional banking sectors. In other word, we can analyze whether the profitability of conventional banks and Islamic bank in Indonesia are driven by the same force. Due to the 
separated model, a dummy variable is no longer needed. The separated model refers to the model of Abduh and Issa (2018).

\section{Results and Analysis}

\subsection{Results}

The aim of this section is to give an overview analysis for the study in terms of the scope of the data and variables that have been used for assessments. Table 2 summaries the descriptive statistics for variables. They are illustrated by its mean, median, minimum, maximum, and standard deviation values.

In the Table 2, the figures of the variables are expressed in forms of ratios, which will narrow the dispersion that could happen due to the huge difference in assets and loans (financing) banks. However, it can't derive a concrete conclusion solely based on descriptive statistics. Thus, in this case, factors such as credit risk is subject to many factors such as size, the bank's risk strategy (adverse risk or otherwise). Therefore, this part will be limited to describing the data by summarizing, organizing, and simplifying it. Thus, it has to picture the data on the data used in this study clearly. The interesting part in this table is the high standard deviation for asset, even higher than its mean. We can interpret it as the deviation of the asset data is not really good.It indicates some outliers in the asset data. This pictures the conventional bank domination in the Indonesian banking industry which can be seen in first chapter of this study.

ROA is one of profitability indicators. It shows how well the bank utilizes their assets to generate returns. Table 2. shows average ROA $0.7763 \%$ with a minimum of $-10.77 \%$ and maximum $6.93 \%$. In terms of size of the bank represented by asset, banks have an average of of Rp. 71038.2 billion with minimum of Rp. 334.22 billion and maximum of Rp. 1236322.9 billion. In terms of capital strength represented by equity/asset ratio; the average is 0.16302 , the minimum is -0.0004 , and maximum is 0.7563408 .

Table 2. Descriptive Statistics and Analysis of Variables

\begin{tabular}{lrrrrr}
\hline & Mean & Median & Max & Min & $\begin{array}{l}\text { Standard } \\
\text { Deviation }\end{array}$ \\
\hline ROA (\%) & 0.7763 & 0.88 & 6.93 & -10.77 & $\begin{array}{r}1.84 \\
\text { Asset (Billion Rp.) }\end{array}$ \\
71038.2 & 15158 & 1236322.9 & 334.22 & 164998.81 \\
Equity/Asset & 0.16302 & 0.1426 & 0.7563408 & -0.0004 & 0.09 \\
Loan/Asset & 0.64195 & 0.6705 & 0.8518862 & 0.2026 & 0.11 \\
GDP growth (\%) & 5.36398 & 5.1193 & 6.1697842 & 4.8763 & 0.46 \\
Inflation (\%) & 4.91738 & 4.8178 & 6.4125133 & 3.1983 & 1.28 \\
\hline
\end{tabular}


In terms of liquidity represented by loan/asset ratio; the average is 0.64195 , the minimum is 0.2026 and maximum is 0.8518862 . In terms of GDP growth, banks have an average of $5.36398 \%$ with minimum of $6.1697842 \%$ and maximum of $4.8763 \%$. In terms of inflation, banks have an average of $4.91738 \%$ with minimum of $3.1983 \%$ and maximum of $6.4125133 \%$.

In the panel data regression, there are a few econometrics model such as Pooled Least Square, Fixed Effect Model, and Random Effect Model. Some tests need to be done to decide the best model used for the study. Chow test is used to decide either PLS or FEM is used and Hausman test is used to decide either FEM or REM is used.

On the Table 3, we can see that the chi-square probability from Chow test is less than $2.2 \mathrm{e}^{-16}$ and the information relating to the alternative hypothesis is showing significant effects. It means that the best model that needs to be chosen according to the Chow test is FEM. According to the Hausmann test, model REM is better than the FEM. because the value is 0.8658 or more than 0.05 .

The test to see the presence of multicollinearity is by looking at the Pearson Correlation Matrix using Eviews 9 software. It can be seen in Table 4, the result of Pearson Correlation Matrix shows that the correlation coefficients among independent variables are low with less than +0.8 or -0.8 , suggesting that a serious collinearity problem is unlikely.

Table 3. Result of Best Model Choice for Combined Regression

\begin{tabular}{llc}
\hline Best model test & Chi-Square Probability & Decision \\
\hline Chow Test & $\begin{array}{l}\text { P-Value }<2.2 \mathrm{e}-16 \\
\text { Hausman Test }\end{array}$ & $\begin{array}{l}\text { Alternative Hypothesis: Significant Effects } \\
\text { P-Value }=0.8658\end{array}$ \\
& $\begin{array}{l}\text { Alternative Hypothesis: One Model is Inconsistent } \\
\text { Source: } R \text { Studio }\end{array}$ & REM \\
& \multicolumn{2}{c}{ SEM }
\end{tabular}

Table 4. Pearson Correlation Matrix

\begin{tabular}{ccccccc}
\hline & $\begin{array}{c}\text { LOAN_PER_ } \\
\text { ASSET }\end{array}$ & LNASSET & INFLATION & GDP & $\begin{array}{c}\text { EQUITY_PER_ } \\
\text { ASSET }\end{array}$ & DUMMY \\
\hline LOAN_PER_ASSET & 1.000000 & 0.080549 & 0.059847 & -0.069449 & -0.117208 & 0.189085 \\
LNASSET & 0.080549 & 1.000000 & -0.074751 & -0.160899 & -0.266362 & -0.093269 \\
INFLATION & 0.059847 & -0.074751 & 1.000000 & 0.021979 & -0.062680 & $8.17 \mathrm{E}-17$ \\
GDP & -0.069449 & -0.160899 & 0.021979 & 1.000000 & -0.064375 & $7.70 \mathrm{E}-18$ \\
EQUITY_PER_ASSET & -0.117208 & -0.266362 & -0.062680 & -0.064375 & 1.000000 & -0.172943 \\
DUMMY & 0.189085 & -0.093269 & $8.17 \mathrm{E}-17$ & $7.70 \mathrm{E}-18$ & -0.172943 & 1.000000 \\
\hline
\end{tabular}

Source: Eviews 9 
Achsani \& Kassim | Determinant of Indonesian Banking Profitability: Case Study Dual Banking System

Table 5. Summary of Random Effect Model Regression for Combined Regression

\begin{tabular}{ccccc}
\hline Variable & Coefficient & Std. Error & T-Statistics & Prob \\
\hline C & -7.884481 & 1.134213 & -6.951502 & $0.0000^{* * *}$ \\
Asset & 0.378715 & 0.058865 & 6.433657 & $0.0000^{* * *}$ \\
Loan/Asset & -0.969539 & 0.646748 & -1.499099 & 0.1344 \\
Equity/Asset & 4.116908 & 0.849638 & 4.845482 & $0.0000^{* * *}$ \\
Dummy & -0.548319 & 0.312284 & -1.755837 & $0.0797^{*}$ \\
GDP & 0.973696 & 0.104760 & 9.294497 & $0.0000^{* * *}$ \\
Inflation & 0.133337 & 0.035729 & 3.731932 & $0.0002^{* * *}$ \\
R-squared & 0.186602 & Adjusted R-squared & 0.177647 \\
F-statistic & 20.83812 & Durbin-Watson stat & 1.602560 \\
Prob(F- & 0.000000 & & \\
statistic) & \multicolumn{5}{c}{ Source: Eviews 9 }
\end{tabular}

The size as represented by bank asset reveals a positive relationship in the model and is statistically significant at $1 \%$. This result is in line with the previous study such as Ali (2018). The result implies that when the size is large enough, banks will earn more through their equity and asset as well. A proxy of capital strength has shown a significantly positive relationship with the profitability at $1 \%$, which explain that banks with stronger capital position is going to generate more profit compared to banks with weaker capital position. The liquidity ratio in the Random Effect Model did not significantly affect the profitability. The same result can also be found in other studies such as Abduh and Issa (2018).

In terms of the macroeconomic conditions, the result shows a positive relationship with significantly affecting profitability at $1 \%$ for either GDP or inflation. The same result can also be found in other studies, such as Abduh, Omar, and Mesic (2013) and Alexiou and Vogiazas (2009). In terms of inflation, this could be ascribed to the ability of management to adequately, though not fully, forecast future inflation, which in turn implies an appropriate adjustment of interest rates to achieve higher profits. In terms of GDP, the stronger economic condition of a country, in this case Indonesia, the more profitable the bank will be. In terms of type of bank, the dummy variable suggests a statistically significant result at $1 \%$ with a negative relationship. In other word, Islamic banks (dummy $=1$ ) are less profitable compared to conventional banks (dummy $=0$ ) in the period studied. Comparing with conventional banks that start its business before the independence of Indonesia, Islamic bank just started its business in 1991. That caused the advantage in capital position for conventional banks. 
Achsani \& Kassim | Determinant of Indonesian Banking Profitability: Case Study Dual Banking System

Due to the significance of the dummy variable in the combined model, it is necessary to run a separated regression in order to see the effects of these determinants on profitability for both Islamic banking as well as conventional banking sectors. According to Hausman test in Table 6, either regression for Islamic banks or regression for conventional banks preferred the random effect model approach. In this approach, it is assumed that nine Islamic banks and 60 conventional have the same intercept.

Table 6. Result of Best Model Choice for Separated Model

\begin{tabular}{lll}
\hline Best model test & Chi-Square Probability & Decision \\
\hline Chow Test & $\begin{array}{l}\text { Islamic Banks } \\
\text { P-Value }=0.01424\end{array}$ & FEM \\
\cline { 2 - 3 } & $\begin{array}{l}\text { Conventional Banks } \\
\text { P-Value }<2.2 \mathrm{e}-16\end{array}$ & FEM \\
\hline Hausman Test & $\begin{array}{l}\text { Islamic Banks } \\
\end{array}$ & P-Value $=0.7333$ \\
\cline { 2 - 3 } & $\begin{array}{l}\text { Conventional Banks } \\
\text { P-Value }=0.209\end{array}$ & REM \\
& & REM \\
\hline
\end{tabular}

Table 7. Summary of Random Effect Model Regression for Islamic Banks Regression

\begin{tabular}{lrrrr}
\hline \multicolumn{1}{c}{ Variable } & Coefficient & \multicolumn{1}{c}{ Std. Error } & \multicolumn{1}{c}{ Z-value } & \multicolumn{1}{c}{ Prob } \\
\hline C & -13.9289 & 3.93816 & -3.5369 & $0.000405^{* * *}$ \\
Asset & 0.70638 & 0.21442 & 3.2943 & $0.000987^{* * *}$ \\
Loan/Asset & -5.13619 & 2.43239 & -2.1116 & $0.034722^{* *}$ \\
Equity/Asset & 15.54231 & 3.93592 & 3.9488 & $7.85 \mathrm{E}-05^{* * *}$ \\
GDP & 1.57843 & 0.40369 & 3.91 & $9.23 \mathrm{E}-05^{* * *}$ \\
Inflation & 0.2849 & 0.14726 & 1.9346 & $0.053035^{*}$ \\
& & & & \\
R-squared & 0.36052 & Adjusted R-squared & 0.31208 \\
F-statistic & 37.2094 & Durbin-Watson stat & 1.602560 \\
Prob(F- & $5.4375 e-07$ & & & \\
statistic) & & & & \\
\hline
\end{tabular}

Table 8. Summary of Random Effect Model Regression for Conventional Banks Regression

\begin{tabular}{lllll}
\hline \multicolumn{1}{c}{ Variable } & \multicolumn{1}{c}{ Coefficient } & \multicolumn{1}{c}{ Std. Error } & \multicolumn{1}{c}{ Z-value } & \multicolumn{1}{c}{ Prob } \\
\hline C & -7.21612 & 1.154563 & -6.2501 & $4.10 \mathrm{E}-10^{* * *}$ \\
Asset & 0.360197 & 0.061953 & 5.814 & $6.10 \mathrm{E}-09^{* * *}$ \\
Loan/Asset & -0.08522 & 0.65375 & -0.1304 & 0.896284 \\
Equity/Asset & 2.35668 & 0.825761 & 2.8539 & $0.004318^{* * *}$ \\
GDP & 0.850056 & 0.099729 & 8.5236 & $2.20 \mathrm{E}-16^{* * *}$ \\
Inflation & 0.115496 & 0.033351 & 3.4631 & $0.000534^{* * *}$ \\
& & & \\
R-squared & 0.15307 & Adjusted R-squared & 0.14413 \\
F-statistic & 85.6653 & Durbin-Watson stat & 1.602560 \\
Prob(F- & 2.22e-16 & & \\
statistic) & & & \\
\hline \multicolumn{4}{c}{ Note: ${ }^{*}$ significant at 10\%, ** significant at 5\%, *** significant at 1\% }
\end{tabular}


Compared to combined regression, the difference relies on the effect of liquidity ratio for the Islamic bank regression. According to Table 7, the liquidity ratio affects the profitability significantly with a negative relationship. This result is in line with Alper and Anbar (2011) and indicates that credit portfolio volume and weak asset quality impact negatively to the profit. This can also be interpreted Islamic banks in Indonesia are too liquid. Banks have much fund available to be disbursed but less demand by the customer. High liquidity will cause inefficiency because holding too much liquidity will increase the cost and soon decrease the profitability. For the conventional bank regression, there is no difference compared to the combined regression which can be seen in Table 8 .

\subsection{Analysis}

Based on the result of dummy variable in the combined model, conventional banks are more profitable in Indonesia. One of the reasons behind this is the presence of Islamic bank in Indonesia is still young compared to the conventional banks. This leads to a low level of awareness of shariah compliant product, especially financial product in the mind of Indonesian people. Despite being the country with the biggest amount of Moslem in the world, some people are still uninterested to shift to Islamic banks. The idea of conventional banking is more familiar than banking that derives the values of shariah. From the perspective of economic scale, Islamic banks still lags behind conventional banks. It could be said that if all the asset of Islamic banks are combined, it is still lower than the asset of the biggest conventional bank in Indonesia. This leads to the low capability of expansion for Islamic bank to widen their business.

From the empirical result in the combined model, it is known that bank size affect profitability positively. When the size of the bank is big, banks will profit from equity and asset. A proxy of capital strength has shown a significantly positive relationship which explain that banks with stronger capital position is going to generate more profit compared to banks with weaker capital position. The liquidity ratio didn't significantly affect the profitability. In terms of the macroeconomic conditions, the result shows a positive relationship with significantly affecting profitability for either GDP or inflation. In terms of inflation, the ability of the management to predictthe value of expected inflation increase the profit. In terms of GDP, the stronger economic condition of a country, in this case Indonesia, the more profitable the bank will be.

Compared to combined regression, there is no difference in terms of significance of the independent variables and its relationship with the dependent variable for the conventional bank regression. The profitability of conventional banks and Islamic bank in Indonesia are driven by the same force. 
It can be seen by the similarity of the independent variables affecting the dependent variable. Only liquidity in the Islamic bank regression shows a different influence. One of the interesting part to be highlighted is that the liquidity ratio affects the profitability significantly with a negative relationship in the Islamic bank regression. This can be interpreted Islamic banks in Indonesia are too liquid. Banks have much fund available to be disbursed but less demand by the customer. High liquidity will cause inefficiency because holding too much liquidity will increase the cost and soon decrease the profitability. The similarity of profitability may be due to the contracts used by Islamic banks are similar to the contracts used by conventional banks. Debtbased contract are dominantly used by conventional banks. Just like Islamic banks in other countries, Islamic banks in Indonesia are also affected by "murabaha syndrome", where financing are concentrated on mark up financing or debt like financing (Miah and Suzuki, 2019). Ideally, Islamic bank should practice profit-loss sharing based financing. This kind of contract is the opposite of debt-based contracts because of the risk sharing characteristic. However, Islamic banks to treat the depositor's money as a liability creates a dilemma to use the PLS based financing due to the high risk. Both types of banks are companies that competes one another to reach the same objective, profit maximization.

\section{Conclusion and Recommendation}

\subsection{Conclusion}

The empirical result in the separated model, there is no difference in terms of the variables that affect the dependent variable for conventional bank regression compared to the combined regression. For the Islamic bank regression, the difference only relies on the effect of liquidity ratio. In this regression, the liquidity ratio affects the profitability significantly with a negative relationship. Based on the result of dummy variable in the combined model, conventional banks are more profitable in Indonesia. The profitability of conventional banks and Islamic bank in Indonesia are driven by the same force. Independent variables that affect Islamic banking profitability behave similarly to independent variables that affect conventional banking profitability. Only liquidity in the Islamic bank regression shows a different influence. 


\subsection{Recommendation}

The findings generate relevant policy implications. Relating to more profitable of conventional bank compared to Islamic bank in Indonesia, low literacy of Islamic bank is the main problem. The idea of Islamic bank is not familiar for people of Indonesia. Since Islamic bank is still young, socialization about the idea of Islamic banking needs to be optimized through various attempts; starting from Islamic related institutions such as mosques and Islamic universities. The socialization needs to be focused on the advantages, patriotic histories, and success stories related to Islamic banking in Indonesia. The low literacy of Islamic banking cause low demands for their products and services. A top-down approach could be a solution for it by creating a law to make an obligation for the government to use Islamic financial product in the region where Islamic values are practiced in the daily life. The development of supporting industries such as halal industry and halal tourism are also important to generate the market. The synergy of halal industry and Islamic banking is also needed in the curriculum in the educational system. Halal industry with its the economic calculation in the future is proofed to attract the attention of millennials. The curriculum of Islamic economic in universities also needs to attract the next generations. Approaches in the curriculum such as halal-haram matters need to be replaced by approaches like financial technology and entrepreneurship.

After increasing the demand of Islamic banking services, the economic of scale needs to be supported by efforts like merger or acquisition of Islamic banks to compete the conventional banks. A strong capital requirement is important for a great Islamic economic ecosystem. Relating to the similar explaining factors of the profitability in both type of banks, there are relevant policy implications as well. Taking consideration of profit-loss sharing contracts, Islamic banks should implement non-financing activities in another way to maximize their profit. Relevant authorities should create the supportive platform for the industry, following the steps of Malaysian IFSA 2013 where attentions are heavily focused on investment account rather than current account/saving account. For the further research, this topic can be done with another method such as dynamic panel to enrich the literature analysis. With a pandemic condition hitting the whole world in 2020, it is also recommended to include the pandemic crisis as an element to be analyzed in the future. 


\section{References}

Abdu, A. (2015). The Impact of Bank Specific and Macroeconomics Conditions on Bank Profitability: Evidence from Sudan. Kuala Lumpur, Selangor, Malaysia: International Islamic University of Malaysia.

Abduh, M., \& Issa, M. S. (2018). Financial crisis and determinants of profitability in Islamic and conventional banks: The study of Kuwait Banking Industry. IQTISHADIA, (11)1, 1-26.

Abduh, M., Omar, M. A., \& Mesic, E. (2013). Profitability determinants of Islamic and conventional banks in Malaysia. Terengganu International Finance and Economics Journal, 3(1), 1-7.

Alexiou, C., \& Vogiazas, S. D. (2009). Determinants of bank profitability: Evidence from the Greek banking sector. Ekonomski anali, (LIV)182, 93-118.

Ali, M. (2018). Determining the factors of profitability in Islamic and conventional Banks of Pakistan; a management perspective. SEISENSE Journal of Management, 1(1), 9-21.

Alper, D., \& Anbar, A. (2011). Bank specific and macroeconomic determinants of. Business and Economics Research Journal, 2(2), 139-152.

Badan Pusat Statistik. (2018). Statistical yearbook of Indonesia 2018. Statistical Yearbook of Indonesia 2018, pp. 1-669.

FAO, IFAD, UNICEF, WFP, \& WHO. (2019). The state of food security and nutrition in the world. Rome: FAO.

Gujarati, D. N. (2003). Basic econometrics. New York: McGraw-Hill Higher Education.

Hidayat, S. E., \& Abduh, M. (2012). Does financial crisis give impacts on Bahrain Islamic banking peformance? a panel regression analysis. International Journal of Economics and Finance, 4(7), 79-87.

Imam, P., \& Kpodar, K. (2015, April). Is Islamic Banking Good for Growth? IMF Working Paper, 15(81), 1-33.

Khediri, K. B., \& Khedhiri, H. B. (2009). Determinants of Islamic bank profitability in the MENA region. International Journal Monetary Economics and Finance, 2(3/4), 409-426.

Masood, O., \& Ashraf, M. (2012). Bank-specific and macroeconomic profitability determinants of Islamic banks The case of different countries. Qualitative Research in Financial Markets, 4(2/3), 255268.

Miah, M. D., \& Suzuki, Y. (2019). Murabaha syndrome of Islamic banks: a paradox or product of the system?. Journal of Islamic Accounting and Business Research, 11(7), 1363-1378. 
Achsani \& Kassim | Determinant of Indonesian Banking Profitability: Case Study Dual Banking System

Otoritas Jasa Keuangan. (2018, June). Snapshot perbankan syariah Indonesia. Snapshot Perbankan Syariah Indonesia 2018, pp. 1-9.

Oxfam. (2018). Reward work, not wealth . Oxford: Oxfam.

Swartz, N. P., Itumeleng, O. O., Wankie, Jeelabdeen, A., \& Kumar, R. (2013). The riba conundrum: The ethical appeal of Islamic banking. Journal of Management and Sustainability, 3(4), 184-194.

World Bank. (2020, 2 11). GINI index (World Bank estimate) - Indonesia. Retrieved from https://data.worldbank.org/indicator/SI.POV.GINI?end=2017\&locat ions $=$ ID\&start $=1984 \&$ view $=$ chart 